\title{
Intragastric nitrites, nitrosamines, and bacterial overgrowth during cimetidine treatment
}

\author{
R W STOCKBRUGGER, ${ }^{*} \mathrm{P}$ B COTTON, $\dagger \mathrm{N}$ EUGENIDES, B A BARTHOLOMEW, \\ M J HILL, and C L WALTERS \\ From the Department of Gastroenterology, The Middlesex Hospital, London, the Central Public Health \\ Laboratory, Bacterial Metabolism Research Laboratory, Colindale, London, and Leatherhead Food \\ Research Association, Leatherhead, Surrey
}

SUMmARY A six week course of cimetidine (1 g/day) healed peptic ulcers in 20 of 23 patients (14 with duodenal ulcer, nine with gastric ulcer). Reduction of basal acid output by $73 \%$ and peak acid output by $36 \%$ led to a rise in concentrations of intragastric aerobic bacteria and nitrate-reducing bacteria. While the mean intragastric concentration of nitrate was unchanged by treatment, there were statistically significant rises in nitrite and $\mathrm{N}$-nitrosamine concentrations. The conversion from nitrates to nitrites was closely related to the occurrence of nitrate-reducing bacteria. In three patients the intragastric milieu had returned to normal two months after cimetidine treatment had been discontinued. Mean nitrite and $\mathrm{N}$-nitrosamine concentrations did not return to pre-treatment levels in the group of eight patients who remained on maintenance cimetidine $(0.4 \mathrm{~g}$ at night-time) for three months after the full dose treatment. This study shows that cimetidine treatment can create an intragastric milieu resembling that of atrophic gastritis. Large scale and long-term studies are necessary to establish whether these findings have any clinical significance.

Cimetidine is effective in the treatment of peptic ulcers; as a result it is widely used, and is increasingly prescribed even in patients with no specific diagnosis. Some minor adverse effects have been described ${ }^{1}$ and there have been anecdotal reports about cimetidine delaying the diagnosis of gastric cancer..$^{3-5}$ The most serious objection to the drug, however, is the suggestion that long-term use might lead to malignant transformation of the gastric mucosa. ${ }^{6}$

There is an increased incidence of gastric dysplasia and gastric cancer in patients with atrophic gastritis with or without pernicious anaemia, and after gastric resection..$^{7-10}$ Most of these patients have hypochlorhydria or achlorhydria, and intragastric bacterial overgrowth. Some of the intragastric bacteria are able to convert endo- and exogenous nitrates to nitrites, leading potentially to the synthesis of $\mathrm{N}$-nitrosamines. These compounds

\footnotetext{
* Present address: Division of Gastroenterology, Medical Department II. Sahlgren's Hospital. University of Goteborg, Sweden.

+ Address for correspondence: Dr. P B Cotton, Department of Gastroenterology, The Middlesex Hospital, London, W1N 8AA.

Received for publication 15 March 1982.
}

are carcinogenic in experimental animals and could contribute to the development of malignancy in atrophic gastritis. ${ }^{11} 12$

The present study was undertaken to see whether acid reduction by short-term and maintenance treatment with cimetidine can induce intragastric bacterial overgrowth with the formation of intraluminal nitrites and $\mathrm{N}$-nitrosamines. ${ }^{13}$

\section{Methods}

\section{PATIENTS}

Twenty-three patients with endoscopically proven peptic ulcers were admitted to the study, which had been approved by the Clinical Investigation Panel at The Middlesex Hospital. They were $18 \mathrm{men}$ and five women; mean age 49 years, mean duration of ulcer disease six years; 15 patients were smokers and eight non-smokers; 14 had duodenal ulcers, nine gastric ulcers. In three of the patients with gastric ulcers, the ulcers were situated in the pre-pyloric region. Fourteen patients had never been treated for peptic ulcer disease; nine had previously received cimetidine but in seven at least 12 weeks had passed 
since last medication. One patient was on maintenance treatment with $400 \mathrm{mg}$ at night when she entered the study, and another patient had been treated with $1 \mathrm{~g} /$ day for one week, because of upper gastrointestinal bleeding, up to 24 hours before the first secretion test.

SCHEDULE OF INVESTIGATIONS AND TREATMENT Within a few days of endoscopy, the patients underwent a gastric secretion test and a collection of specimens for microbiology and biochemistry. Cimetidine treatment ( $200 \mathrm{mg}$ tds before meals and $400 \mathrm{mg}$ at night) was started immediately after these tests, and continued until they were repeated six weeks later. The repeat tests were undertaken in the morning in the fasting state, the patients having had $400 \mathrm{mg}$ of cimetidine the previous night, and $200 \mathrm{mg}$ two hours before the tests. Check endoscopy was performed, and patients with unhealed ulcers were excluded from further study.

Eleven patients with healed ulcers were randomly divided into two groups: group $\mathbf{A}$, three patients were given cimetidine (400 $\mathrm{mg}$ at night) for one month only; nasogastric intubation was then repeated two months after cessation of treatment; group B, eight patients received longer maintenance treatment; seven with cimetidine ( $400 \mathrm{mg}$ at night) for another three months, and one with $1 \mathrm{~g} /$ day for six months. A third nasogastric intubation for collection of gastric juice was performed on the morning after the last dose had been taken.

Twelve patients could not undergo maintenance treatment; three had unhealed ulcers; one had complicating disease, three were not examined for technical reasons, and five patients did not attend.

TECHNICAL METHODS

Specimens for microbiological and biochemical analysis were aspirated from the stomach after passing a sterile tube via the nose, and discarding the initial asirate. This method was initially validated by taking specimens from the nostril and palate.

\section{Microbiology}

Specimens were transported without delay to the microbiology department; gastric contents were diluted with broth, and viable organisms were estimated by the Miles and Misra technique on blood agar and McConkey media, incubated aerobically at $37^{\circ} \mathrm{C}$. Organisms were identified using standard techniques.

Nitrate and nitrite analysis 5 millilitres of gastric juice were buffered to $\mathrm{pH} 9.4$ with $5 \%$ borax buffer. The sample was deproteinised using zinc acetate in acetic acid and potassium ferrocyanide solution. ${ }^{14}$
Alumina cream ${ }^{15}$ was used to remove the colour from the gastric juice, and nitrite was measured by means of the diazo compound formed between sulphanilic acid and N-1-naphthylethylene diamine di-HC1. ${ }^{11}$ Nitrate was determined after conversion to nitrite by incubating the deproteinised, decolourised gastric juice with a bacterial suspension of $E$. coli having high nitrate reductase activity. Nitrate-reducing bacteria $\quad 0.5 \mathrm{ml}$ of gastric juice was inoculated into $4.5 \mathrm{ml}$ glycerol broth and frozen. Samples were stored at $-20^{\circ} \mathrm{C}$ until bacteriological studies were carried out. Nitrate reducing activity was assessed by the method of Cowan and Steel, ${ }^{16}$ and the number of nitrate-reducing organisms was obtained by reference to 'mean probable number' tables. $^{17}$

$N$-nitroso-compounds Sulphamic acid was added at a concentration of $0.5 \% \mathrm{~W} / \mathrm{v}$ to the residue of about $10 \mathrm{ml}$ gastric juice, to prevent nitrosation as an artefact during storage. $\mathrm{N}$-nitroso-compounds were extracted into ethyl-acetate from the acid milieu; thus any such compounds with a basic function are not included in the extraction. $\mathrm{N}$ nitrosamines and $\mathrm{N}$-nitrosamides were determined by the group selective procedures of Walters et al. ${ }^{18}$ in which such compounds are denitrosated selectively to nitric oxide for measurement using a chemiluminescence analyser. All types of $\mathrm{N}$-nitrosocompounds have been found to respond to this procedure. Of the compounds potentially formed from nitrite and nitrate in a biological matrix only nitrolic acids and S-nitrothiols have also been found to yield nitric oxide under the same conditions as $\mathrm{N}$-nitroso-compounds.

\section{Gastric secretion tests}

Gastric secretion tests were performed by standard technique. ${ }^{19}$ Small amounts of gastric juice were used to estimate the $\mathrm{pH}$ to the nearest half unit by pH-paper (Merck). Basal secretion was measured during four 15-minute periods and the maximal secretion for another hour after an intramuscular injection of pentagastrin ( $6 \mu \mathrm{g} / \mathrm{kg}$ body weight). Gastric acid output was expressed in the traditional terms $^{20}$ of $\mathrm{BAO} / \mathrm{h}$ and $\mathrm{PAO} / \mathrm{h}$ after measuring volume and hydrogen ion concentration for each sample.

Statistical analysis of the data was performed using Student's $t$ test for paired data and linear regression analysis.

\section{Results}

HEALING OF ULCERS

Ulcers had healed after six weeks' treatment in 20 of the 23 patients (13 of 14 with duodenal ulcer, and 
seven of nine with gastric ulcer). Eleven of the patients with healed ulcers were placed on maintenance treatment.

\section{REDUCTION OF ACID OUTPUT}

The $\mathrm{pH}$ of the first basal gastric sample rose from $1.76 \pm 2.1$ (mean \pm SEM) before treatment, to $5.34 \pm 0.43$ after treatment $(\mathrm{p}<0.001)$ (Table 1). Reduction of basal acid output (BAO) was 73\% $(p<0.001)$ and of peak acid output (PAO) 36\% $(\mathrm{p}<0.001)$ for all patients. Reductions for duodenal ulcers were: BAO $79 \%(p<0.001)$, PAO $31 \%$ $(\mathrm{p}<0.001)$, and for gastric ulcers were: BAO $61 \%$ $(\mathrm{p}<0.01)$, PAO $43 \%(\mathrm{p}<0.001)$. The three patients whose ulcers did not heal showed a reduction of $\mathrm{BAO}$ and PAO similar to that in the patients whose ulcers healed.

\section{BACTERIAL OVERGROWTH AND CHANGES IN}

NITRATES, NITRITES, AND N-NITROSAMINES

The mean concentration of bacteria (per ml gastric juice) before treatment was $\log _{10} 0.82 \pm 0.68$ SEM for all patients and had risen significantly to $\log _{10}$ $4.91 \pm 0.59$ after treatment $(p<0.001)$ (Table 1$)$.

After six weeks of cimetidine $1 \mathrm{~g} /$ day four patients had sterile gastric juice in the fasting state. Fourteen of the remaining 19 patients had intragastric growth of upper respiratory tract flora only (including Staphylococcus aureus, Streptococcus viridans. Staphylococcus epidermis, Neisseria spuria); five patients had an intragastric flora of faecal type either alone or in combination with upper respiratory tract flora. Intragastric growth of candida was found in four of 23 patients (ranging from $\log _{10} 3 \cdot 84$ to $4 \cdot 28$ ). None of the patients reported symptoms which could be related to bacterial or fungal overgrowth.

There was a close correlation between bacterial counts and basal $\mathrm{pH}(\mathrm{r}=0.822, \mathrm{p}<0.001)$ and with BAO $(r=0.664, p<0.001)$ but no correlation with PAO $(r=0.402, p>0.05)$.

The rise in concentration of total aerobic bacteria was paralleled by a significant rise in the number of nitrate-reducing bacteria (Table 1). The correlation between total bacteria/ml and those capable of nitrate-reduction was significant $(r=0.631, \mathrm{p}<0 \cdot 01)$ (Fig. 1).

The mean concentration of nitrates did not fall significantly during treatment, but there was a significant rise for nitrites in the total group of patients; the rise in the group of patients with gastric ulcers was not significant (Table 2).

There was a significant correlation between the concentration of nitrate-reducing bacteria and the ratio of nitrites to the total of nitrates plus nitrites (Fig. 2). Treatment also induced a significant increase in the $\mathrm{N}$-nitrosamine concentrations for the total patient group and for the subgroup of patients with gastric ulcers; the rise in the subgroup of patients with duodenal ulcers was not significant (Table 2).

\section{MAINTENANCE TREATMENT}

Complete gastric secretion tests were not repeated in the 11 patients given any maintenance treatment; instead, the $\mathrm{pH}$ of a basal specimen of gastric juice was measured, and specimens were prepared for microbiological and biochemical analyses as described above.

In the three patients in whom maintenance treatment had been discontinued two months before re-examination (group $\mathrm{A}$ ), the $\mathrm{pH}$, bacterial concentrations, and levels for nitrites had returned to pre-treatment values, but two nitrosamine-levels were still raised (52 and $120 \mu \mathrm{g} / \mathrm{l}$ as $\mathrm{NN}$ pyrrol respectively). In the eight patients on three months' maintenance treatment (group B), the mean basal $\mathrm{pH}$ had fallen from $6.7 \pm 0.4$ to $4.5 \pm 0.9(\mathrm{p}<0.02)$. Mean counts of nitrate-reducing bacteria (Fig. 3a) and concentrations of nitrate, nitrite, (Fig. 3b) and $\mathrm{N}$-nitrosamines (Fig. 3c) were not, however, statistically significantly different from those after full dose treatment.

Table 1 Gastric $p H$ and bacterial counts (mean $\pm S E M$ ) in 23 patients with peptic ulcers before and after six weeks of cimetidine treatment

\begin{tabular}{|c|c|c|c|c|}
\hline & & $\begin{array}{l}\text { All patients } \\
n=23\end{array}$ & $\begin{array}{l}\text { Duodenal ulcer } \\
n=14\end{array}$ & $\begin{array}{l}\text { Gastric ulcer } \\
n=9\end{array}$ \\
\hline \multirow[t]{2}{*}{$\mathrm{pH}$} & Before & $\begin{array}{r}1 \cdot 76 \pm 0 \cdot 21 \\
p<0.001\end{array}$ & $\begin{array}{r}1.57 \pm 0.09 \\
p<0.001\end{array}$ & $\begin{array}{c}2.07 \pm 0.55 \\
p<0.01\end{array}$ \\
\hline & After & $5 \cdot 34 \pm 0 \cdot 43$ & $5 \cdot 35 \pm 0 \cdot 53$ & $5 \cdot 33 \pm 0 \cdot 82$ \\
\hline \multirow[t]{2}{*}{$\begin{array}{l}\text { Total aerobic bacteria } \\
\text { ( } \log _{1} / \mathrm{ml} \text { gastric juice) }\end{array}$} & Before & $\begin{array}{r}0.82 \pm 0.68 \\
p<0.001\end{array}$ & $\begin{array}{r}0.11 \pm 0.11 \\
p<0.001\end{array}$ & $\begin{array}{l}1.93 \pm 1.07 \\
\text { NS }\end{array}$ \\
\hline & After & $4.91 \pm 0.59$ & $5 \cdot 59 \pm 0.55$ & $3.85 \pm 1.03$ \\
\hline \multirow[t]{2}{*}{$\begin{array}{l}\text { Nitrate-reducing bacteria } \\
\left(\log _{10} / \mathrm{ml} \text { gastric juice }\right)\end{array}$} & Before & $\begin{array}{r}0.29 \pm 0.23 \\
p<0.001\end{array}$ & $\begin{array}{c}0.10 \pm 0.10 \\
p<0.01\end{array}$ & $\begin{array}{c}0.61 \pm 0.21 \\
p<0.05\end{array}$ \\
\hline & After & $2 \cdot 67 \pm 0.54$ & $2.97 \pm 0.72$ & $2 \cdot 12 \pm 0.75$ \\
\hline
\end{tabular}




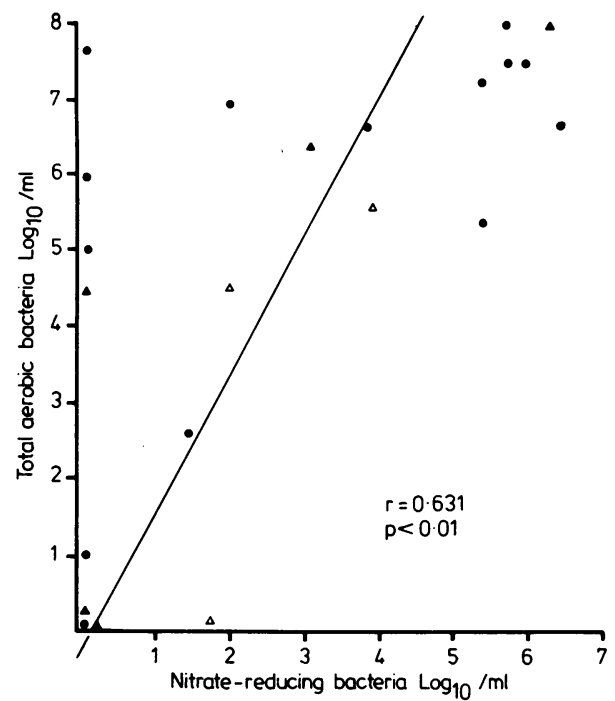

Fig. 1 Correlation between total aerobic bacteria and those capable of nitrate reduction ( $n=22)$. In this and subsequent figures, the symbols used are: $\bullet$ duodenal ulcer, $\mathbf{\Delta}$ gastric ulcer, $\triangle$ prepyloric gastric ulcer.

\section{Discussion}

This study confirms that cimetidine is a potent inhibitor of basal and stimulated gastric acid output; the ulcer healing rate of $87 \%$ after treatment with 1 $\mathrm{g} /$ day for six weeks is comparable with other reports. Parallel to the reduction in acid output, we showed a marked alteration of the intragastric milieu. There was a significant rise in bacterial concentrations; some of the bacterial species were capable of reducing nitrates to nitrites, and we found statistically significant increases in nitrite and $\mathrm{N}$ nitrosamine concentrations after short-term treatment.

Our samples were taken in the morning, in the

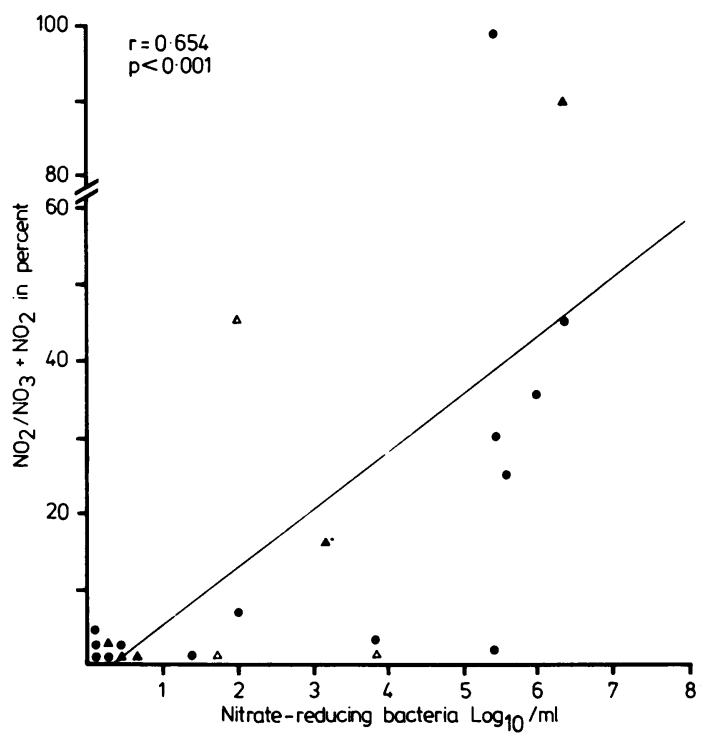

Fig. 2 Correlation between nitrate-reducing bacteria and ratio of nitrite converted from nitrate in percentage - that is, nitrite/nitrate + nitrite $-(n=22)$.

fasting state. Despite suggestions to the contrary, ${ }^{21}$ the values probably reflect the situation throughout the night. ${ }^{22}{ }^{23}$ Bacterial counts of more than $10^{5}$ organisms $/ \mathrm{ml}$ in the upper gastrointestinal tract have been judged to be pathological. ${ }^{24}$ Some, however, would regard such bacterial overgrowth to be significant only if it includes faecal type organisms, ${ }^{25} 26$ whose presence indicates that a resident flora has been established and that the juice is not bacteriocidal at any time during the day or night. An overgrowth of faecal type organisms is seen in most patients with achlorhydria due to atrophic gastritis, ${ }^{27}$ and was observed in four of our patients after cimetidine treatment. Our documented increases in $\mathrm{N}$-nitroso compounds after

Table 2 Intragastric concentrations (mean \pm SEM) of nitrate, nitrite, and N-nitrosamine before and after six weeks of cimetidine treatment

\begin{tabular}{|c|c|c|c|c|c|}
\hline & No. & & All patients & Duodenal ulcer & Gastric ulcer \\
\hline \multirow[t]{2}{*}{ Nitrates $(\mu \mathrm{mol} / \mathrm{l})$} & 22 & Before & $\begin{array}{c}313 \pm 39 \\
\text { NS }\end{array}$ & $\begin{array}{l}339 \pm 51 \\
\text { NS }\end{array}$ & $\begin{array}{c}268 \pm 56 \\
\text { NS }\end{array}$ \\
\hline & & After & $272 \pm 36$ & $278 \pm 74$ & $260 \pm 75$ \\
\hline \multirow[t]{2}{*}{ Nitrites $(\mu \mathrm{mol} / \mathrm{l})$} & 22 & Before & $\begin{array}{c}3.2 \pm 1.7 \\
p<0.05\end{array}$ & $\begin{array}{r}1.6 \pm 0.7 \\
p<0.05\end{array}$ & $\begin{array}{l}5 \cdot 9 \pm 4 \cdot 7 \\
\text { NS }\end{array}$ \\
\hline & & After & $52 \cdot 1 \pm 21 \cdot 9$ & $52 \cdot 0 \pm 20 \cdot 8$ & $16 \cdot 3 \pm 7 \cdot 8$ \\
\hline \multirow[t]{2}{*}{$\mathrm{N}$-nitrosamines ( $\mu \mathrm{g} / \mathrm{l} \mathrm{NN}$-pyrrol) } & 20 & Before & $\begin{array}{r}14.1 \pm 3.7 \\
p<0.01\end{array}$ & $\begin{array}{l}15 \cdot 9 \pm 4 \cdot 8 \\
\text { NS }\end{array}$ & $\begin{array}{c}10.9 \pm 5.4 \\
p<0.001\end{array}$ \\
\hline & & After & $26 \cdot 3 \pm 3 \cdot 4$ & $23 \cdot 7 \pm 4 \cdot 1$ & $31 \cdot 1 \pm 5 \cdot 3$ \\
\hline
\end{tabular}



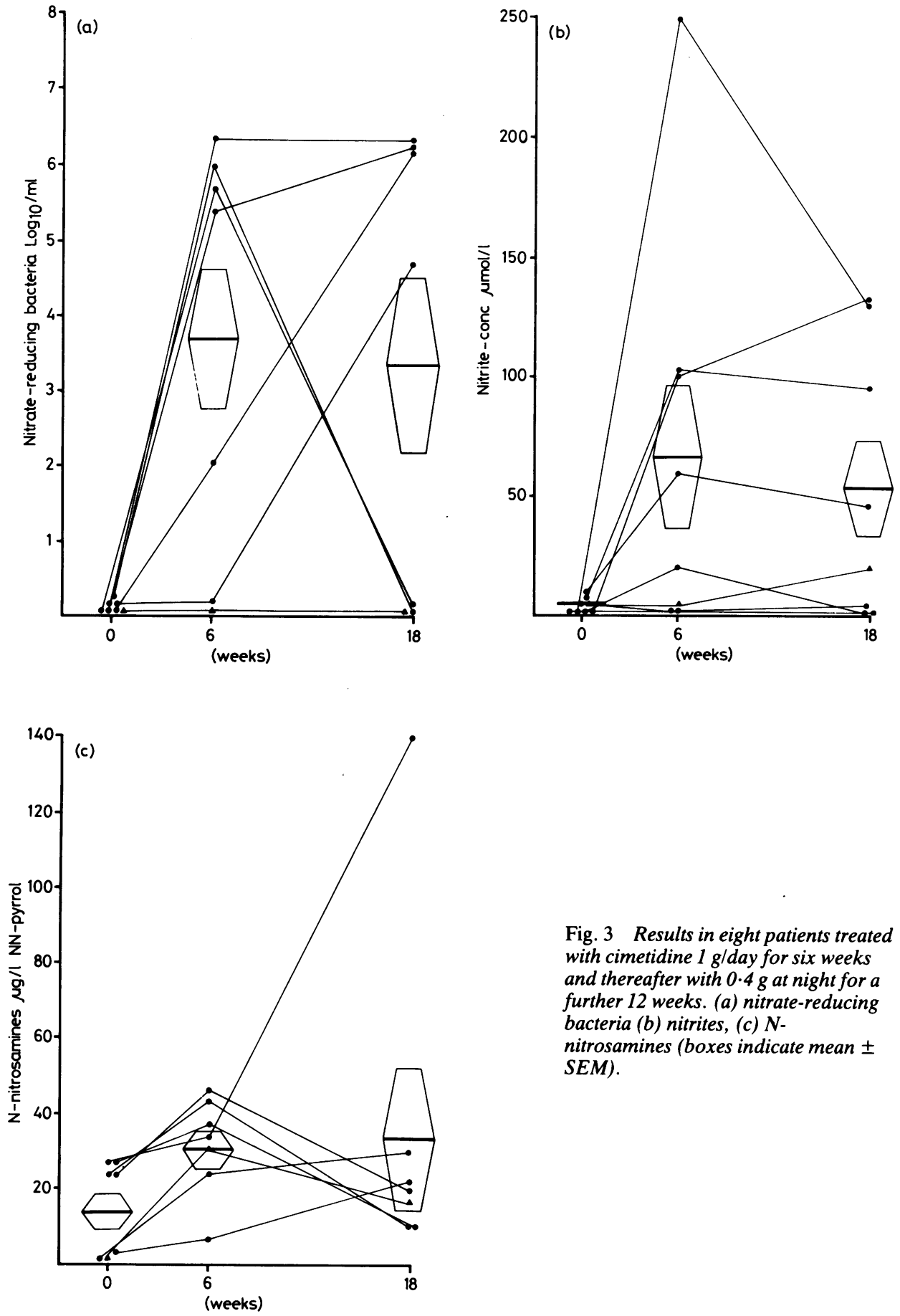

Fig. 3 Results in eight patients treated with cimetidine 1 g/day for six weeks and thereafter with $0.4 \mathrm{~g}$ at night for $a$ further 12 weeks. (a) nitrate-reducing bacteria (b) nitrites, (c) $\mathrm{N}$ nitrosamines (boxes indicate mean \pm $S E M)$. 
cimetidine treatment must be assumed to result from nitrite produced by bacterial action; the assay did not include $\mathrm{N}$-nitroso-cimetidine and other compounds with a basic function.

The clinical significance of these changes is open to speculation. ${ }^{28}$ The role of $\mathrm{N}$-nitrosamines in human gastric cancer remains to be established. The rises seen in this study were relatively small, and the mean level after treatment remained within the pre-treatment range; only a few values exceeded those earlier obtained in normal subjects in the same laboratory. They were, however, similar to those found using an identical technique in a small number of patients with pernicious anaemia, who do have an increased risk of gastric cancer (in preparation). There is also a parallel with patients who have undergone surgical treatment for peptic ulceration, which can result in intragastric conditions similar to those seen after treatment with cimetidine in full dosage. The increased risk of gastric cancer in such patients does not appear until about 10 years have passed. ${ }^{10}$

Full dose treatment with cimetidine is usually given for short courses. Our results in a small number of patients have not contraindicated such use with good clinical indications. Many patients are now prescribed low dose maintenance treatment with cimetidine. It is of concern that the mean $\mathrm{N}$-nitrosamine levels remained raised in this study after three months' maintenance treatment at lower dosage, and even two months after the end of treatment in two patients. These aspects require longer term and larger scale studies before any clinical conclusions can be attempted.

We are pleased to acknowledge support from Smith Kline and French (England), the Special Trustees of The Middlesex Hospital, and the Cancer Research Campaign.

\section{References}

1 Pariente AE, Nouel $O$. Cimetidine-induced bone marrow suppression. Dig Dis Sci 1980; 25: 396-8.

2 The $\mathrm{H}_{2}$ File. London: Franklin Scientific Projects, 1981.

3 Elder JB, Ganguli PC, Gillespie IE. Cimetidine and gastric cancer. Lancet 1979; 1: 1005-6.

4 Taylor RH, Menzies-Gow N, Lovell D, La Brooy SJ, Misieiwicz JJ. Misleading response of malignant gastric ulcers to cimetidine. Lancet 1978; 1: 686.

5 Stoddard CJ, Smith JAR, Johnson AG. Cimetidine, delay in diagnosis and carcinoma of the stomach. Lancet 1980; 2: 199-200.
6 Reed PI, Cassell PG, Walters CL. Gastric cancer in patients who have taken cimetidine. Lancet 1979; 1: 1234-5.

7 Siurala M, Eramaa E, Tapiovaara J. Pernicious anaemia and gastric carcinoma. Acta Med Scand 1959; 164: 431-36.

8 Zamcheck $N$, Grable E, Ley A, Norman L. Occurrence of gastric cancer among patients with pernicious anemia at the Boston City Hospital. N Engl J Med 1955; 252: 1103-10.

9 Siurala M, Lehtola J, Ihamaki T. Atrophic gastritis and its sequelae. Results of 19-23 years follow-up examinations. Scand J Gastroenterol 1974; 9: 441-6.

10 Domellof L, Eriksson S, Janunger KG. Carcinoma and possible precancerous changes of the gastric stump after Billroth II resection. Gastroenterology 1977; 73: 462-8.

11 Ruddell WSJ, Bone ES, Hill MJ, Blendis LM, Walters CL. Gastric juice nitrite: a risk factor for cancer in the hypochlorhydric stomach. Lancet 1976; 2: 1037-9.

12 Ruddell WSJ, Bone ES, Hill MJ, Walters CL. Pathogenesis of gastric cancer in pernicious anaemia. Lancet 1978; 1: 521-3.

13 Ruddell WSJ, Axon ATR, Findlay JM, Bartholomew BA, Hill MJ. Effect of cimetidine on the gastric bacterial flora. Lancet 1980; 1 : 672-4.

14 Ito Y, Yodoshi M, Tanaka J, Iwaida M. Comparison of two methods and improvements for colorimetric determination of nitrite in cod roe. $J$ Food Protection 1979; 42: 715-8.

15 Elliott $\mathbf{R}$, Porter A. A rapid cadmium reduction method for the determination of nitrate in bacon and curing brines. Analyst 1971; 96: 522-7.

16 Cowan ST, Steel KJ. Manual for the identification of medical bacteria. London: Cambridge University Press, 1974; 176-7.

17 Meynell GG, Meynell E. Theory and practice in experimental bacteriology. Cambridge: Cambridge University Press, 1965: 231.

18 Walters CL, Downes MJ, Edwards MW, Smith PLR. Determination of a non-volatile $\mathrm{N}$-nitrosamine on a food Matrix. Analyst 1978; 103: 1127-33.

19 Hassan MA, Hobsley M. Positioning of subject and nasogastric tube during a gastric secretion study. $\mathrm{Br}$ Med J 1970; 1: 458-60.

20 Baron JH. Clinical tests of gastric secretion. London: Macmillan Press, 1978.

21 Muscroft JJ, Youngs DJ, Burdon DW, Keighley MRB. Cimetidine is unlikely to increase formation of $\mathrm{N}$ nitroso compounds in patients taking a normal diet. Lancet 1981; 1: 408-10.

22 Longstreth GF, Go VLW, Malagelada J-R. Cimetidine suppression of nocturnal gastric secretion in active duodenal ulcer. $N$ Engl J Med 1976; 294: 801-4.

23 Pounder RE, Williams JG, Russell RCG, MiltonThompson GJ, Misiewicz JJ. Effect of cimetidine on 24 hour intragastric acidity in normal subjects. Gut 1976; 17: 133-8.

24 Drasar BS, Hill MJ. Human intestinal flora. London; Academic Press, 1974.

25 Metz G, Gassull MA. Drasar BS, Jenkins DJA, Blendis LM. Breath hydrogen test for small intestinal 
colonisation. Lancet 1976; 1: 668.

26 Lauterberg BH, Newcomer AD, Hofmann AF. Clinical value of the bile acid breath test. Mayo Clin Proc 1978; 53: 227-33.

27 Drasar BS, Shiner M, McLeod GM. Studies on the intestinal flora. I. The bacterial flora of the gastrointestinal tract in healthy and achlorhydric persons. Gastroenterology 1969; 56: 71-9.

28 Editorial. Does cimetidine cause gastric cancer? $\mathrm{Br}$ Med J 1981; 1: 1178-9. 